\title{
Voice of the Muse, Word of the Church
}

\section{The Parable of the Rich Man and Lazarus in Late Medieval Latin Poetry}

The earliest writers of Christian Latin poetry were not different from their pre-Christian forerunners in attending to both message and craft, seeking effectively to express truth, human and divine. Yet in several ways it was a new poetry. Emerging in the fourth century with new freedom, a new mission, and a new message, Christian poets wrote mainly to praise God, but their way of doing this was to put the new gospel wine into old Roman bottles for the educated elite, to provide memorable lessons in style and elegance for generations of students, and to engage in debates over doctrine in order to teach the truth of the faith as perceived. Christian poetry was born as liturgical hymns for use alongside the Psalms and as supplements to scriptural readings and sermons. As part of that function from the beginning, Christian poetry communicated biblical lessons and the theology underlying them. The first Christian Latin hymns by Hilary of Poitiers (c. 315-c. 368) champion Nicene orthodoxy. Hilary's first hymn, "Ante saecula qui manes”, includes doctrinally precise formulas like "ut genitor, quicquid inest sibi, ... totum in unigenam ediderit deum". ${ }^{1}$ Following Hilary, Ambrose (c. 340 - 397) composed hymns against his doctrinal rivals the Homoians. After Ambrose's death, his hymns for feast days continued to engage in controversies because Augustine of Hippo (354-386) and Celestinus I (d. 432) used them in their disputes with rival new theologies.

Besides hymns, narrative versifications were composed to present the Bible's stories and the Church's lessons vividly and elegantly, joining and rivaling the beloved ancient epics. Poems based on episodes from the Bible constitute a major instance of a cultural transformation and assimilation of classical literary and rhetorical form by Christian writers and teachers. ${ }^{2}$ Deliberate, conscious attention to poetics is always present, but the new poets, responding also to epic poetry's potential for signification and even direct commentary, made hermeneutics, exegesis, and theological interpretation a part of the compositions. The contribution that poetic form made to biblical narrative is that of the voice of the Muse in the expression of the word of God. If we seek a verb to describe the complex action, the writers may be said mainly to have paraphrased or amplified the biblical text, so long as those terms are understood to include both esthetics and ideas. When the fifth-century poet Sedulius, for example, amplifies the details of the water changing into wine at Cana by the verb

1 Dunkle (2016) 34.

2 For an overview of the concept of reception see Martindale (1993). The broader concept of transformation has been gaining a useful conceptual framework and vocabulary. See Böhme, Bergemann (eds.) (2011). 
rubescunt, readers may ask whether he embellished a narrative detail with an allusion to the sacramental fullness of water and wine as a figure of Christ's water and blood flowing from the cross. ${ }^{3}$

The richness of certain biblical versifications on many levels was also compatible with the progressive nature of medieval schooling, from rudimentary grammar to philology and rhetoric, a setting in which the schoolmaster explicated the features of the historical, literary, moral, or doctrinal meaning to address his students' needs. The value seen in Juvencus, Arator, Avitus, and Sedulius is evident from their dominance of the early medieval school curriculum, even over the Bible itself, as is often pointed out. ${ }^{4}$ What lessons were to be derived from the study of those biblical poems? Classical rhetorical paraphrase gave elegant form and diction to the scriptural narrative, but since the subject matter was the Scriptures, poets had an enormous added weight of presenting a sacred narrative in a faith community. Further, the guiding belief was that the Bible is univocal, presenting many facets of the one message of creation, fall, and redemption. While the accounts of creation and resurrection of Genesis and the Gospels were versified more often because of their centrality and dramatic content, most parts of the univocal Bible were versified, the Book of Revelation being the main exception. Some poets were more theologically competent than others. Avitus, for example, did not write an epic on Genesis and Exodus so much as depict the celestial cycle of sin, redemption, and sacramental renewal, focusing his narrative elements on events from the first two books of the Bible but cross-referencing them with Gospel texts. ${ }^{5}$ Typology or allegory connect the Testaments to one another and both to the Church's central teachings.

The Gospel parables communicate essential Christian teachings and are among the versifications of the Bible in all periods. Scholars have paid less attention to them than to the versifications of Genesis and the Gospel accounts of Christ's life likely because of the parable-poems' relative brevity and frequently obvious moral messages. That richer exegetical traditions, however, are included in poems treating the parables is what will be explored here through a case study of poems that have the parable of the rich man and Lazarus as their subject. The parable in Luke, likely already transformed from earlier sources with its events occurring both on earth and in the afterlife, was further transformed in its reception by Christian readers. The Gospel lection (Lk. 16.19-31) was read and preached every year on the second Sunday after Pentecost (First Sunday after Trinity), and it was abundantly commented on

3 Sedul., A solis ortus cardine 50; Bianco (1993) 56.

4 E.g., Lapidge (2006) 11-12.

5 Dinkova-Bruun (2007) 318-320, also dissatisfied with the division of early biblical poetry into three classes according to genre: full-scale epics (Avitus, SHG), carmina (De Sodoma), and secondary paraphrase (Dracontius, De Laudibus Dei), and into two classes according to source: Old Testament and New Testament works, instead proposes a division according to subject, as those addressing the Fall and those addressing the Redemption. While that classification is helpful, it is still important to remember the essential interconnection between those endpoints. 
in sermons and depicted frequently in art. The parable thus provides a well-stocked exegetical laboratory in which to examine the purpose and method of the versifications.

The story of the anonymous rich man who fails to show mercy to poor Lazarus, with each experiencing a reversal in the afterlife, presents a clear moral lesson on the relative value of material and spiritual goods and a warning to be charitable. The parable is also readily adaptable to rhetorical shaping, especially by antithesis, a pattern that is so prominent in Christian discourse. A homily by Augustine sustains the following rigid antithetical pattern, replete with rhetorical questions, over sixteen sentences:

Quid est illud? Quod oculus non vidit. Quid est hoc? Quod fidelis oculus non sitit. Quid est illud? Quod invenit Lazarus ulcerosus. Quid est hoc? Quod habuit dives inflatus. Quid est illud? Quod perire non potest. Quid est hoc? Quod teneri non potest ... . ${ }^{6}$

Patristic and medieval commentators also contrasted the rich man's neglectfulness with the empathy of the dogs who came to lick Lazarus's wounds, showing how responsibility and kindness do not need great material resources. Farther afield is the observation that while riches are dangerous, it is not riches themselves but personal vices that condemn the rich, vices that can all be traced back to the sin of pride. Jerome, for example, using a powerful anaphora, points out that the rich man was condemned for nothing else, not even the vice of greed, but rather for his pride: "Diues iste purpuratus et splendidus non accusatur quod auarus fuerit, non quia res alienas tulerit, non quia adulter fuerit, non quia aliquid mali fecerit: sola in illo condemnatur superbia". ${ }^{7}$ Commentators also went beyond ethics to explain theological implications. Ambrose teaches that the abyss teaches the impossibility of personal atonement after death: "Inter hunc igitur diuitem et pauperem chaos magnum est, quia post mortem nequeunt merita mutari".

Poets of the later Middle Ages inherited those exegetical traditions and communicated them to their readers, using fewer narrative verses and more commentary. Odo of Cluny's tenth-century Occupatio stands as a virtually unique example of a mainly narrative biblical epic. Newly composed commentaries in verse form competed with narrative epics in the school curriculum. ${ }^{9}$ The twelfth century's growing interest in philosophical method as systematized by Aristotle, and the development of philosophical-allegorical poems like the Cosmographia of Bernard Sylvestris (fl. 1130 -1150), further reduced explicit narrative versification of the Bible. ${ }^{10}$ The as-

6 Aug., Sermo 19.4, PL 38.136, CCSL 41.257. Among medieval writers this same moral emphasis can be found, for example, in Hugh of St. Victor PL 176.608D, and Hugh of Rouen, PL 192.1157B.

7 Jerome Hom. in Luc., de Laz. et divite CCSL 78.508.

8 Ambrose, In Luc. Exp., VIII.18 on Lk. 16.24.

9 Dinkova-Bruun (2007) 321.

10 Lapidge (2006) 28. 
cendancy of metaphysics by the systematic theologians from the twelfth and thirteenth centuries is seen further to have relegated poetry's role from the position of being a vehicle for expressing truth to a more primitive, inventive phase of rational thought, good at best for offering embellishment of truths arrived at philosophically, and at worst, a "devil's tool" to corrupt mankind. ${ }^{11}$ Thus, in harmony with this new emphasis, poets in the scholastic period wrote biblical poetry that shifted the balance away from narrative paraphrase to systematic lessons on Scripture in verse. ${ }^{12}$ In the actual poems, however, there survives a strong interrelationship between narrative and commentary, allusion and direct expression.

The Aurora of Petrus de Riga (1140 - 1209) typically represents the new emphasis of biblical poetry with its attention paid to overt commentary and exegesis. ${ }^{13}$ Some of Petrus's poems are not even based on the Bible itself but on prose biblical commentaries. His "Exodus", for example, is seen to be derived from commentary on Exodus by Bruno, Bishop of Segni (ca. 1045-1123). ${ }^{14}$ For all the shift in proportion, however, the practice of inserting explicit theological commentary in biblical poems was not a new phenomenon in the twelfth century. Avitus of Vienne at the dawn of the sixth century inserted the parable of the rich man and Lazarus into his Spiritual History at Book 3, "De sententia Dei", on the sentencing of Adam and Eve. He did this to teach by example, not the obvious moral lesson about greed and charity but the derivative theological lesson of the impossibility of repentance after death: "Namque obitum quemdam casu tum pertulit ipso, / Perdita ne precibus lacrymisve reduceret ullis". ${ }^{15}$ That analogy is all the more theologically poignant because, in light of Adam's continued bodily life, the death that is mentioned here is unmistakably meant as that of his soul, a spiritual death that would be signalled as the most permanent kind without the poet's insertion of other parables like the Good Shepherd and Lost Coin, and the typological narratives in Books 4 and 5 pointing to Baptism. Avitus's lesson is that just as the rich man had no recourse, so too Adam now be saved only by the Redeemer.

The later medieval poetry is also both direct in its commentary and allusive in its narrative paraphrase elements. What is different about the later verse commentaries on Scripture is the linear nature of their comments, following the order of events in the biblical text instead of focusing on a single exegetical line to illustrate a main lesson. This change of form corresponds to the express aims of the synthetic commentaries of the period with the goal of encapsulating theological doctrines. But both the earlier rhetorical epics that are richer in their narrative elements, and the

11 Greenfield (1981) 53.

12 Dinkova-Bruun (2007) 325.

13 The parable of the rich man and Lazarus is the subject of a rhythmical poem dating from the $9^{\text {th }} \mathrm{c}$. Mainly a close paraphrase of the biblical narrative, the poem also expands the narrative details and contains both direct and indirect exegesis. See Stella (1993) 330.

14 Lapidge (2006) 29; 32.

15 Avitus SHG III.313-314. 
later verse commentaries that are richer in explicit exegetical lessons utilize both direct commentary and poetic allusion.

In terms echoing St. Paul and Origen, Petrus Riga says that he wrote to instruct both the inexperienced and the learned: "Accedat igitur parvulus ad huius libri lectionem quia in eo invenitur lac parvulorum, accedat et perfectus quia in eo inveniet solidum cibum ... Accedat similiter ingeniosus vel studiosus, quia reperiet unde possit et debeat exercere ingenium suum". ${ }^{16}$ Natural to this effort, the Aurora includes many verses addressing the parables and their lessons in history, allegory, and mysticism at various levels of meaning. With the broad aim of commenting on the entire Bible, Petrus did not produce a comprehensive paraphrase but rather a commentary with condensed narrative, albeit one still capable of presenting exegesis through poetic allusion.

Petrus's treatment of the parable of the rich man and Lazarus is one of nine major parables included in his verses on the New Testament. It is in six elegiac couplets, the preferred meter for sententious poetry, wherein the poet immediately exploits the stark distinction of the two main characters. From the patristic era into the Middle Ages, commentators emphasized the naming of Lazarus but not the rich man. ${ }^{17}$ Petrus therefore took the weak homo quidam designation of the rich man in the Vulgate and weakened it further by removing it from the subject position to the oblique genitive case, making the subject rather the rich man's sumptuous feasts and radiant clothing:

Semper splendebant cuiusdam diuitis esce,

Et uestes eius purpura, bissus erant.

Lazarus, on the other hand, is the first word of the couplet describing him:

Lazarus esuriens mendicabat prece micam,

Sed non audiuit mica petita precem (2053-2056).

Just as the naming of Lazarus is a consistent exegetical motif, his name here occupies the first position. Petrus could rely on readers experienced with the sermon tradition to understand the deliberate change of syntax.

Then, even more starkly than the Gospel account, the third couplet bluntly emphasizes the equal death of the two characters (each one simply obit) followed immediately by a summary of their unequal aftermath: "Dives obit, rapit hunc infernus, traditur igni; / Pauper obit, fruitur pace, quiete, bonis” (2057-2058). Petrus chose to comment on the allegorical associations rather than the sufficiently clear moral import. Couplets four through six focus on the allegorical symbolism. And they do this

16 Petrus Riga Aurora, ed. Beichner (1965) vol. 15-6. All citations of the Aurora are from this edition. 17 The fact that Lazarus was named led some exegetes to argue that the story was not a parable at all but a historical account of a historical occurrence. 
both explicitly and also allusively. First, the rich man is to proud Judea as Lazarus is to the humble Gentiles: "Diues Iudeam signat, qui floruit olim. / Deliciis, opibus, unde superba fuit. / Gentes quas curat confessio signat egenus" (2059-2061). Examples of this explicit exegesis are abundantly preserved. ${ }^{18}$ The next line in this uninterrupted sentence explaining the symbolism of Lazarus as the Gentiles reads as a narrative paraphrase of Lc 16.21: "Cuius curabat uulnera lingua canum" (2062). In this context, however, the narrative reference to the dogs is surrounded by explicit commentary explaining the symbolism of the details. Immediately before this line Petrus interpreted poor Lazarus as the Gentiles, nourished by their confession of faith, and the final couplet relates the allegory of the rich man's five brothers as the five books of the Law: "Quinque notant fratres Iudeos legis habentes / quinque libros” (2063-2064). Within Petrus's emphasis on commentary, the reference to the dogs' therapeutic tongues functions allusively by representing the prelates of the Church, who bring to the people the word of God and cleansing of their spiritual sores, thus continuing the flow of symbolism. The comparison of preachers to dogs is well developed before, during, and after Petrus's time. In the patristic era Ambrose and Gregory I used the comparison. ${ }^{19}$ In the twelfth century a homily of Godfrey of Admont (d. 1165) contains the explicit exegesis of the dogs who came to lick Lazarus's sores as preachers: “Quicunque mendicus ille est, qui vere se mendicum, pauperem dico et egenum, cognoscit ... huic cupienti saturari, canes veniunt, ulcera lingunt, dum praedicatores sancti, canes significati, languentis animae vulneribus et lingua exhortationis, et lingua consolationis subveniunt". ${ }^{20}$ After Petrus, the same explicit analogy is preserved in a homily by the Catalan cleric Vincent Ferrer (1350-1419) in his sermon for the first Sunday after Trinity. ${ }^{21}$ The connection is also evident through the constructed etymology of the Domini-canes, the Order of Preachers.

Thus, the rich man and Lazarus symbolize the Pharisaic Jews and Gentiles, those rich and proud in the Law in the first case, and those aware of their need, hungry for divine knowledge, and patient in hope of rescue in the other. That exegesis is extended with a traditional interpretation of the five brothers whom the rich man wants belatedly to warn. They are five because they symbolize the Pentateuch. As with the naming of Lazarus, this motif is widely represented in commentaries from all periods. ${ }^{22}$ The Aurora is rightly understood as a verse commentary on the Bible, thus dif-

18 E. g., Greg., Hom. 40. Bede, In Luc. Exp. V.16.

19 Ambr. Hex. VI.4.23; Gregory I Exp. Cant. II.17 (PL 79.500B).

20 PL 174387 A-401B. The Glossa ordinaria, commenting on Lc 16.22, preserves a related interpretation, that of the dogs' tongues signifying the tongues of flatterers who perversely praise faults in us that we reprehend in ourselves ( $P L$ 114.316).

21 Sivera (ed.) Sermo 24 (1932), 1.269.

22 Augustine reflects on the reason for five brothers: "appellati enim sunt quinque, quia sub lege detinebantur quae per Moysen data est, qui libros quinque conscripsit”. Aug. Quaest. Ev. II.38. The interpretation is also preserved in the Catena aurea 16.6. And close to the time of the Aurora, 
fering from the more allusive commentaries of the biblical epics. But while allusiveness in narrative is subordinate to explicit didacticism, both types of commentary operate in the passage.

Despite the Aurora's great length, Giles of Paris (Aegidius Parisiensis, 1162-1224) produced between 1200 and 1208 two large redactions with supplements in his own skillfully crafted elegiac couplets. ${ }^{23}$ Giles wrote that he intended to reorder the entries, correct discrepancies, and add commentary on themes which Petrus treated insufficiently or omitted out of weariness or ignorance. ${ }^{24}$ In his second redaction he added the Evangelium Aegidii, within which he included interpolations and additions to Petrus's poem on the parable of the rich man and Lazarus. It is one of eight parables selected for expansion out of the nine that Petrus had versified. The added verses are over twice the length of Petrus's versification, twenty-six lines to twelve. He devoted all of them to expound on the theme of the rich man being without a name while Lazarus is both named and known by God. This motif is present in Petrus, but in Giles it takes center stage.

As mentioned, the naming and witholding of a name is present in the Gospel parable but is not emphasized, but from the patristic era on, commentators reflected on it. Augustine made this emphasis in a sermon on the parable: "Nominabatur dives ille ab hominibus, pauper tacebatur: contra Dominus pauperem nominavit, divitem

Bruno of Segni's Commentary on Luke speaks of this interpretive strain as allegory with an alternate interpretation of the five brothers: Haec autem si allegorice intelligantur, dives iste Judaicum populum significat. Solus enim Judaeorum populus legis, et prophetarum divitiis, et deliciis locupletatus, omnes alios despiciebat, nullisque, in cibis spiritualibus, quibus abundabat, communicare volebat. Hoc enim vitio, usque nunc laborat populus ille, et sic omnia celat, ac si revelando perdere debuisset. Qui purpura quidem in regibus, in sacerdotibus autem bysso induebatur. Cujus quinque fratres quinque populi partes intelliguntur. Reges scilicet, et sacerdotes, Scribae, et Pharisaei, et caetera populi multitudo. Mendicus vero, id est, Lazarus, qui adjutus interpretatur, quem Dominus adjuvit et a mortis periculo liberavit, gentilis populus est (Commentaria in Lucam pars secunda PL 165425 A). Rupert of Deutz is referenced also as including this typology: PL $170 \mathrm{n}$. 240. Within the general connection with Jews and Gentiles, Augustine locates the Gentiles in the dogs who lick Lazarus's (i.e., Christ's) wounds, while the rich man (Jews) ignore Lazarus. Thus Aug.: in divite intelligantur superbi Iudaeorum, ignorantes Dei iustitiam, et suam volentes constituere (Quaest. Ev. II.38; also cited in Aquinas, Catena aurea ch. 61, lect. 6). Also, Quorum in typum vulnerati Lazari clamor ad Deum pervenit, dum secundum nomen suum adjutus, Lazarus enim interpretatur adjutus, "ab angelis in sinu Abrahae portaretur, dives autem" per quem Judaicus designatur populus, scilicet copia legis in elatione abutens, "in inferno sepeliretur (Luc. XVI)" Nec discutere quis audeat, vel reprehendere profunda Dei judicia (Rupert of Deutz, Comm. Job. 168 1131B).

On the psychological level, an alternative strong tradition interprets the rich man's five brothers as the five senses. See Jerome In Laz. et Div. 86; Bede In Luc Ex. V.16; Catena 16.6. Glossa ordinaria. The Glossa ordinaria also includes the parallelism between the rich man and Lazarus and the Jews and Gentiles in its commentary under allegory.

23 Beichner (ed.) (1965) II.584. All citations of Giles are from this edition.

24 Beichner (ed.) I, xx-xxiv and Giles's own verse prologues, I.12-13. 
tacuit”. ${ }^{25}$ Other early examples are extant in Jerome, Gregory, and Bede. In the ninth century Rabanus Maurus (d. 856) composed a homily reflecting on the way the public will know rich men's names more readily than the names of poor men: Certe plus solent in populo nomina divitum, quam pauperum sciri. Quid est quod Dominus de paupertate et divite verbum faciens, nomen pauperis dicit, nomen divitis non dicit, nisi quod Deus humiles novit atque approbat et superbos ignorat”. ${ }^{26}$

In the twelfth century Bruno of Segni made it part of his commentary on Luke. ${ }^{27}$ The exegesis became part of the Catena aurea. ${ }^{28}$

Giles takes up the same line of argument: "Nam mundo celebres sunt per sua nomina dites; / pauper ubique latet sed neque nomen habet” (1995-1996). To that general premise he adds a rhetorical amplification:

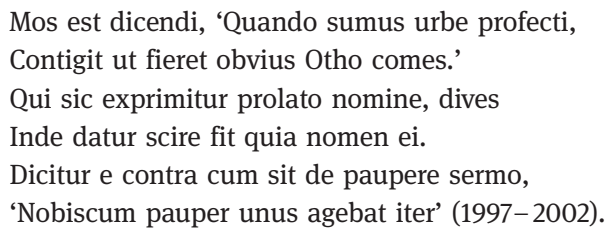

Then, to the amplified premise, Giles shows that the Gospel word shows the divine priorities, where the rich man is introduced, as he observes, absque ulla additione (2008 - 09), but Lazarus expresse (2010). Lastly, a moral invective against worldliness is tersely delivered by the contrast between the culmen mundi and aula Dei (20152016). Giles thus gives an amplification of Petrus's commentary through a focused exemplum featuring the difference between, as he had already written, "publica lex mundi" and "lex benigna Dei" (1994), and states that the Lord himself presented this parable contra dites (1991).

Composed of an example but no narrative, Giles's verse interpolation is to be described neither as a paraphrase nor a linear commentary but as a verse homily, or better, a collation, a type of reflection on a small select aspect of a scriptural text or liturgical reading that was popular in the medieval exegetical tradition. And while Giles displays rhetorical and poetic skill, he directs all amplifications to the

25 Aug. Sermo 41.4, CCSL 41.498. Cf. Jerome Hom. in Luc. de Lazaro et divite: Lazarus pauper, quoniam sanctus erat, nominatur: iste uero diues et superbus nec nomine quidem dignus habitus est. homo quidam erat diues. propterea dico quidam: quia quasi umbra praeteriit (CCSL 78). Cf. Gregory Mor. I.8; Bede In Luc. Exp. V.16 534C.

26 Rabanus, Hom. II.77 PL 110.294D.

27 Lazarus, qui jacebat ad januam ejus, ulceribus plenus, cupiens saturari de micis quae cadebant de mensa divitis; et nemo illi dabat. Sanctorum etenim nomina scripta sunt in coelis; malorum vero nomina non sunt scripta in libro vitae. Unde et hoc loco divitis nomen non dicitur; mendici vero dicitur. Hic Lazarus vocatur. Ille quomodo vocetur nescimus. Talibus enim dicturus est Dominus: 'Amen dico vobis, nescio vos.' Quid igitur mirum si illum nescimus, quem nescit ille qui omnia scit. Comm. in Luc., pars secunda PL 165 422CD.

28 Aquinas, Cat. Aur. 16.4. 
poem's didactic aims. Readers can appreciate the poetic skill in service to a lesson on the heavenly priorities discoverable in the language of the world and the language of Scripture. For this reason, it seems just to soften the harsh criticism of the editor Beichner, who suggested that it would be better, when reading the Aurora, to neglect the interpolations of Giles. To do so is to miss his distinct interplay between theology and poetry.

The parable of the rich man and Lazarus is also the subject of verses included in the biblical anthology from York Cathedral. ${ }^{29}$ This anonymous compendium dating from the thirteenth century contains both well-known and unique poetic entries, with selections ranging from Sedulius to Geoffrey of Vinsauf and beyond. The treatments of individual biblical episodes appear to be free-standing versifications, and the editor Greti Dinkova-Bruun describes the collection as "without sustained coherent structure", "uneven", and "miscellaneous", but the section that includes poems on the New Testament as "the most homogeneous part of the anthology", "the most original", intended to tell the story of salvation through its selections for other writers to draw inspiration and moral example. ${ }^{30}$ The poetry treating the parable of Lazarus and the rich man consists of poems numbered 48 to 55 in the collection, a series of couplets and longer stanzas of various meters totaling 22 lines. The verses are not attested to elsewhere and have not yet received detailed study. The editor notes only one verse as an echo from a poem by Hugh 'Primas' ${ }^{31}$ The interplay of poetic and exegetical elements in the lines, however, is noteworthy, especially when the verses are read alongside various individual parts of the biblical parable.

In the first couplet, the different worldly situation of the two protagonists is illumined by grammar and syntax: "Victus, uestis, opumque domi dum diues habundat, / Lazarus ante fores esurit, alget, eget” (48.1-2). The first line focuses on the possessions of a rich man, while the second line names Lazarus first before his hardships. The alliteration but more so the syntax of the lines helps to bring out this point: Not only is the rich man named after his possessions, those possessions are described in three nouns in the genitive case (one is tempted to say possessive): victus, uestis, opum, and the emphasis on the location in a house, domi. The only noun associated with Lazarus, by contrast, without possessions, is fores, those of the rich man where Lazarus sat suffering, described in three intransitive verbs.

The second couplet engages the reader directly with moral commentary: "Cerne ualere parum thesaurum diuiciarum", followed by a stark description of their afterdeath rewards that also reemphasizes the name of Lazarus and not the neutral diues here but the condemnatory auarus: Cum requies Lazarum teneat; cremet ignis auarum" (49.1-2). The third couplet engages in typology, reflecting on the relationship of suffering to virtue, which is presented not as an automatic or casual relationship.

29 Dinkova-Bruun (2002) 99-100.

30 Dinkova-Bruun (2002) 66.

31 Dinkova-Bruun (2002) 100, n. 102. 
Rather, patient endurance is what transforms suffering into virtue, as the poet explains by way of a typology connecting Lazarus and his Old Testament prototype, Job: "Lazarus meritis multus, Iob rarus habetur: / Infirmi multi, patiens uix inuenietur" (50.1-2). The typological link with Job is meant to teach that suffering becomes virtue through patient endurance, alluded to by the name Job, a motif that endured in the exegetical tradition. Long after Giles, preachers like Lawrence of Brindisi (1559-1619), for example, were still bringing out the typology and parallelism in homilies, as here, where Lawrence celebrates the virtue of both men in their suffering and poverty: Ostenditur in duobus hominibus his, quam nobilis sit natura humana cum virtute tantum, licet nullum aliud coniunctum habeat bonum, in Lazaro, in quo nonnisi patientia elucet, sicut in patientissimo Iob in sterquilinio; et quam vilis eadem sine virtute sit, licet omne aliud bonum possideat, in epulone. ${ }^{32}$

The fourth couplet exhorts the reader to recognize both that he himself is a Lazarus, which is to say, to understand that life entails suffering, and that he can also be a Job, who makes virtue from that suffering. That lesson is reinforced with a return in stanzas five and six to the reversal of the conditions of Lazarus and the rich man in life and after death. This final section reinforces the contrasting earthly and heavenly rewards through skillful and theologically relevant word-play, as on purpura and pauper and splendida cena and celi amena (54.1-2).

The general effect of all the couplets combined is to highlight the theme of reversal. The versification can be accurately described as a commentary in verse, like the Aurora of Petrus; but besides direct commentary, the verses offer lessons allusively, in the manner of the earlier biblical epics, inviting attentive readers to perceive the lessons in the word choice and selection of details.

In contrast to Petrus, the author of the Dyalogus de divite et Lazaro, preserved in a fourteenth-century manuscript from the Benedictine monastery at Oudenberg, Flanders, returned to the inventive and self-consciously rhetorical approach to biblical versification. The piece shows that the scholastic verse commentary did not eliminate rhetorical versifications of the Bible, as stylized, moralistic poetry regained favor toward the birth of the Renaissance. The Dyalogus represents a direct verbal exchange between the rich man and Lazarus in their respective afterlives. It comprises 107 lines: dactylic hexameters interspersed among the principal meter of trochaic septenarius, 'vagantenzeile', or the meter of the vagantes, vagabonds, in which the Carmina Burana and the works of the Archpoet are composed. The nineteenth-century editor of the Dyalogus, Johannes Bolte, argued that one cannot properly consider this verse dialogue between the rich man, bound for Hell, and Lazarus, already in heaven, as a dramatic paraphrase of the biblical account of the parable; for the poet confines himself to the rhetorical depiction of the contrasts between the life of luxury of the selfish bon vivant and his punishment in the beyond. Bolte, however, further suggested that the demands of the poetic form and the requirements of rhyth- 
mical verse compromised the poet's freedom of thought and clarity of expression. ${ }^{33}$ Bolte's standard of clear expression may have been scholastic commentaries like the Aurora. As has been our intention to show, however, readers familiar with exegetical traditions connected with the parable will find more substantial content in the Dyalogus than Bolte's assessment suggests.

The poem supplements the gospel narrative by building on a framework of rhetorical antithesis, a practice illustrated above in reference to Augustine's homily on the parable. Gregory Hays has noted the tendency in Christian discourse to frame biblical episodes by means of contrasts between two figures (Cain/Abel; Abraham/ Lot; Jacob/Esau; Mary/Martha): The figures allow instances of paired contrasts that "can be traced as a rhetorical device back to the Greek rhetorician Gorgias (c. 483-376 B.C.)". Hays adds, however, that "their frequency in preaching owes something to sheer rhetorical effectiveness, but it also reflects a deeper pattern inherent in Christian discourse". ${ }^{34}$ In the present study, interest is precisely in that deeper pattern which Hays mentions. Rhetorical contrast may provide the frame, but what the poet puts into the frame requires choices about substance, act, motivation, and meaning, through which poets reflect the values and lessons expressed in homilies, commentaries, and compendia like the Glossa ordinaria or the Catena aurea. Even the form of a dialogue in which the rich man is imagined speaking in defense of himself, amplifying his few words in the scriptural account, is a rhetorical framework that already appeared in the early Christian exegetical tradition to teach theological lessons. ${ }^{35}$

The dialogue begins dramatically as the first eight stanzas engage the three parties in a debate where both rivals give opening speeches to Abraham as judge. The rich man opens by bewailing his suffering in words not of repentance but anguish. Lazarus gives a caution about the rich man's falseness through words: "fallax fallere verbis te laborat" (6). The rich man repeats his expression of loss, and Lazarus names his lack of pity as the cause, "cum misereri / Nolueris miseri" $(9-10)$. Then, the rich man abandons his pretense and states his enduring disdain for Lazarus. He says heaven won't accept Lazarus because of his physical condition. Lazarus affirms that he will be accepted, while the rich man will be taken to Hell; but the rich man's initial disdain is coupled with envy. Assuming the role of a preacher, Lazarus explains that heaven rejects those of little faith, the rich, and the unjust, unless Christ saves them. This is the first of Lazarus's condemnations, which are all qualified by conditional statements that highlight the essential intervention of a savior and the wasted opportunity for prior forgiveness: "Iste locus modicos fidei, dites et iniquos / Non recipit nisi quos Christus sibi fecit amicos” (24-25).

Stanza 9 makes a major turn in the debate, where the rich man begins his own defense as a praise of wealth for the worldly honors that accompany it. Lazarus takes

33 Bolte (ed.) 261. All citations of the Dyalogus are from this edition.

34 Hays (2012) 224.

35 E.g., Pet.Chrys., Sermo 122, PL 52.533. Peter's sermon, like the poetic dialogue under study, focuses on the final scene, after the rich man sees Lazarus in the bosom of Abraham. 
a new turn as well in refuting the rich man directly, which he never does in the Gospel version. The rich man abandons all pretense of repentance but rather boasts to be elevated, magnificent, and happy. In stanza 11, the final line of his argument is descriptive of his disposition: "perque potentatum me glorior esse beatum" (34). Lazarus refutes that claim by inverting, mocking the same expression: "Iure potentatus numquam potes esse beatus" (35), again with the lost chance for forgiveness presented in a conditional clause: "sis ni purgatus totius labe reatus" (36).

The rebuke does not deter the rich man, who presses his defense of wealth and the instant gratification it brings; nor Lazarus, who observes that disproportionate wealth displeases God and introduces destruction:

\begin{tabular}{|c|c|}
\hline $\begin{array}{l}\text { Ultra modum cupere } \\
\text { Cum deus in opere }\end{array}$ & $\begin{array}{l}\text { census non est sensus, } \\
\text { tali sit offensus. }\end{array}$ \\
\hline $\begin{array}{l}\text { Dum res solent crescere, } \\
\text { Accensum generat magni }\end{array}$ & $\begin{array}{l}\text { crescit et accensus. } \\
\text { custodia census }(41-44) \text {. }\end{array}$ \\
\hline
\end{tabular}

This theme is familiar in the exegetical tradition regarding the parable of the rich fool of Luke's Gospel. Bede, for example, wrote: "Is qui sibi thesaurizat et non est in deum diues stultus est et in nocte rapiendus". ${ }^{36}$ Regarding the diction, the poem's editor has noted the dual significance of accensus, as both the fire of longing and as an allusion to hellfire. To be noticed also is the poet's echo of Juvenal's proverb, "miseria magni custodia census". ${ }^{37}$

In stanza 15 the rich man's self-incrimination worsens: he claims that he was content not to give food satis pleno ... egeno, "to a beggar who was already full enough" (46). Lazarus corrects him: "Querens de micis, me pulsas et maledicis" (48). Peter Chrysologus in the fifth century, amid four sermons on the parable, observed that the rich man, suffering more from Lazarus's reward than his own situation, continued to treat Lazarus with contempt: "Quod agit dives, non est novelli doloris, sed livoris antiqui, coelo magis incenditur quam gehenna ... Adhuc divitem malitia non deserit, quem iam possidet poena". ${ }^{38}$

The rich man then even tries to blame his servant for neglecting Lazarus:

$\begin{array}{lc}\text { Precepi multociens, } & \text { quod fragmentum detur, } \\ \text { Ut tu vel esuriens } & \text { quivis saturetur; } \\ \text { Sed non facit serviens } & \text { omne, quod iubetur. } \\ \text { Si fuit insipiens, dominum cur pena sequetur? (51-54) }\end{array}$

That strategy recalls the rich man in Jerome's sermon on this parable, where Jerome imagines words of defense the rich man might have used were it not for the fact that

36 Bede In Luc. Exp. IV.12.

37 Juv. Sat. 14.303.

38 Pet. Chrys., Sermo 122 (PL 52.543) 
Lazarus was plainly visible at his door: "Iacebat ad ianuam, ne diues diceret, non uidi, in angulo fuit, aspicere non potui, nemo mihi nuntiabat ... eo tempore quando te greges seruorum et clientum prosequebantur". 39

Subsequent exchanges are summarized as follows: Lazarus says he found the animals kinder than the rich man, but the rich man advances criticism of Lazarus's vile face, scabrous skin, raucous breathing, and asks why so vile a person, rejected on earth is received into heaven. He suggests he will infect the healthy ones there. The rhetorical diatribe shows his complete lack of progress during the dialogue. Lazarus comments that bodily health produces nothing unless it is joined by a pure mind. He does not deride physical grace but spiritual deficiency. He says that sickness that leads to salvation is more effective than well-being that kills a man. In further defense of wealth, the rich man quotes Horace, "Et genus et formam regina pecunia donat" (68), further confirming his failure to repent. ${ }^{40}$ The rich man remains out of touch with his present situation and thus cannot be repentant. Lazarus states that no one lacks beauty who is adorned by "alma fides", an epithet for the holy (Christian) faith, common to biblical poetry. ${ }^{41}$ The rich man boasts that he "plucked many flowers from the world" ("flores collegi de mundo"), and he equates himself with any rich and powerful patron or king ("par ego regi"), claiming that he did only what he willed to do. In a subtle shift of syntax, Lazarus counters that pride, wealth, and honors are the 'flowers of the world' ("mundi flores"), that "spoil the character" ("violant mores") and, in the end, bring pain. This echoes Augustine, "Mundi flores quomodo colligeres, qui a spinis non revocas manum?"42 Lazarus soon after completes the allusion: "Quasi spine / pungunt [diviciae] in fine" (83-84).

The rich man asks why he is condemned for riches, to which Lazarus replies "Quia nimis in eas ardes totus datus" (86). The line presents a suggestive syntax: Ardes can be read as the subordinate verb under quia: "because you burn for them beyond measure, having surrendered totally. Ardes can also be read as the main verb: "because you were totally given over to them beyond measure, you are burning now". As a poetic allusion, the syntax ambiguity symbolizes the close connection between greed and hellfire. And then Lazarus quotes from the late antique Distichs, traditionally attributed to the Elder Cato: "Despice divicias, si vis animo esse beatus!” (89)..$^{43}$

39 Jerome Hom. in Luc., de Laz. et divite (CCSL 78.507-516).

40 Hor.,Ep. I.6.37.

41 Cf. Pruden., Psycho., Arator De Actu Apost. 714, Ven. Fort., Carm. X.14.2, Pauli. of Nola, Carm. 14.80; 19.200; Ennod., 128.8, Anthol. Lat. 80(91aR). Also in epigraphy: See TLL Epigraphicae Vol. 1, 252 col. 2 s.v. almus.

42 Aug. Sermo 38.8.11. The context in Aug. 38 is that the material world, even in its troubled condition, is loved; Aug. asks 'what if it were peaceful?, to which he refutes the questioner: How would you cling to something beautiful, who so embrace what is foul.

43 Cato Dist. 4.1. 
The closing four stanzas return to the rich man's now desperate but still hedging language of repentance. The rich man presents any sin on his part, however, only as a possibility through a series of conditional sentences and indirect questions: "Quidquid mali fecerim, penitet et fleo. / Culpam si gemuerim, remittatur reo; / Volo, si peccaverim, reformari deo" (90-92). The last sentence of the stanza summarizes the rich man's case: "Penitet et facto torqueor ipse meo. (93).

Finally, in a reiteration of the doctrinal lesson we heard from Ambrose and Avitus at the beginning of our discussion, Lazarus reminds the rich man of the futility of repentance after death, and so through him the poet exhorts the audience to repent now.

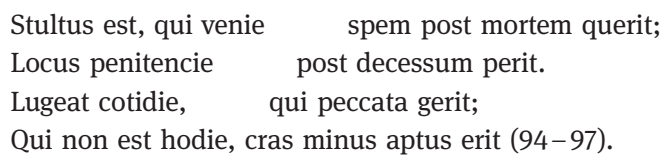

An allusion to the great abyss between them leads to the final stanza, an appeal by the rich man to God and Abraham, just as he did in the first stanza. The rich man pronounces his own death and guilt, and his own typological similarity to the Pharisees, who, not in the literal world of the parable but according to its theological significance, were to deny Christ. It is a commentary, made allusively, but a commentary nonetheless.

The final stanza displays the poet's craft, with all four lines in matched rhyme and parallel syntax:

\footnotetext{
Ha quid agam! morior miser ego reus!

Non est dolor gravior, quam sit dolor meus.

In inferno crucior tamquam pharizeus.

Parce mihi, senior, tu mihi parce, deus! (104-107).
}

We have examined four versifications based on the parable of the rich man and Lazarus composed during the later Middle Ages. The poet Petrus wrote a verse commentary in the Scholastic manner, which Giles supplemented with a verse homily or collation using rhetorical amplification. The anonymous York poet wrote couplets on the theme of reversal, and the anonymous poet of the Dyalogus wrote a rhetorical exercise with theological commentary. Those pieces provide a valuable case study of a much larger collection of poems devoted to the gospel parables, which still constitute a group of works not thoroughly examined by scholars. The intentional variations of genre and diction in the four works notwithstanding, the versifiers of the Gospel parable produced works that are a skillful and theologically astute blend of overt commentary and subtle allusion, elements that offer the patient reader a dynamic interplay between tradition and innovation, theology and poetry. 


\section{Bibliography}

\section{Primary Sources}

Beichner (ed.) (1965): Petrus Riga, Aurora: Petri Rigae Biblia versificata; a verse commentary on the Bible, 2 vols., Notre Dame, Ind.

Bolte (ed.) (1891): Johannes Bolte, "Dyalogus de Divite et Lazaro" in: Zeitschrift für deutsches Altertum und deutsche Literatur 35, 257-262.

Dinkova-Bruun (2002): Greti Dinkova-Bruun, "Medieval Latin Poetic Anthologies (VII): The Biblical Anthology from York Minster Library (Ms. XVI Q 14)”, in: Medieval Studies 64, 61-109.

Lawrence of Brindisi (1928-1956): S. Laurentii a Brundusio, Opera omnia, vol. 8, dominicalia, Padua.

Sivera (ed.) (1932): Vincent Ferrer, Sermons a cura de Josep Sanchis Sivera, 2 vols., Barcelona.

\section{Secondary Sources}

Bianco (1993): Maria Grazia Bianco, “A proposito di aquae rubescunt hydriae”, in: Augustinianum $33,49-56$.

Böhme, Bergemann (2011). Hartmut Böhme, Lutz Bergemann, et al. (eds.), Transformation. Ein Konzept zur Erforschung kulturellen Wandels, Munich.

Dinkova-Bruun (2007): Greti Dinkova-Bruun, "Biblical Versifications from Late Antiquity to the Middle of the Thirteenth Century: History or Allegory?", in: Poetry and Exegesis in Premodern Latin Christianity: The Encounter between Classical and Christian Strategies of Interpretation, ed. Willemien Otten and Karla Pollmann, Leiden.

Dunkle (2016): Brian P. Dunkle, Enchantment and Creed in the Hymns of Ambrose of Milan, Oxford, UK.

Greenfield (1981): Concetta Carestia Greenfield, Humanist and Scholastic Poetics 1250 To 1500, Lewisburg, Pa.

Hays (2012): Gregory Hays, “Prose Style”, in: Oxford Handbook of Medieval Latin Literature, Ralph Hexter, David Townsend eds. Oxford, UK, 218-235.

Lapidge (2006): Michael Lapidge, "Versifying the Bible in the Middle Ages", in: The Text in the Community: Essays on Medieval Works, Manuscripts, Authors, and Readers, Notre Dame, Ind. Martindale (1993): Charles Martindale, Redeeming the Text: Latin Poetry and the Hermeneutics of Reception, Cambridge, UK.

Stella (1993): Francesco Stella, La poesia carolingia latina a tema biblico. Spoleto. 
